pp. $302-316$

\title{
Institutional Quality and Foreign Direct Investment Inflows: Evidence from Cross-country Data with Policy Implication
}

Submitted 02/02/20, $1^{\text {st }}$ revision 02/03/20, $2^{\text {nd }}$ revision 29/03/20, accepted 20/04/20

\author{
Chinmaya Behera ${ }^{1}$, Bikash Ranjan Mishra ${ }^{2}$,
} Biswashree Tanaya Priyadarsini ${ }^{3}$, Lopamudra D. Satpathy ${ }^{4}$

\begin{abstract}
:
Purpose: The study examines the impact of institutional quality on Foreign Direct Investment (FDI) inflows for emerging economies from South Asiain the period 2002-2016. Other economic factors such as globalisation, financial development, and GDP are also considered.
\end{abstract}

Design/Methodology/Approach: The study uses Im-Pesaran-Shin (IPS) panel unit root test to check stationarity property. It uses cross dependency $(C D)$ and cross-sectional augments IPS tests to check cross-sectional dependency and heterogeneity across the group countries. Next, it uses panel ARDL-PMG tests to check the existence of long-relationship among variables. Then, we apply the panel Granger causality test to check the direction of causality. Finally, for the robustness of results, we use the Pedroni co-integration technique.

Findings: The study finds the existence of a long-run relationship between institutional quality and FDI inflows. Other economic factors such as globalization and financial development show long-run and strong causality with FDI inflows. However, the short-run unidirectional causality from institutional quality to FDI inflows is not found for all the countries. Finally, institutional quality strongly causes FDI inflows provided paired with either globalisation or financial development.

Practical Implications: Institutional quality increases the FDI inflows. Therefore, policymakers should focus on institutional quality along with globalization and financial development for higher inflows of FDI in emerging countries.

Originality/Value: The study considers institutional quality as one of the inputs for FDI inflows in selected emerging economies from South Asia. Further, it creates an institutional quality index for the emerging countries to examine the impact on FDI inflows.

Keywords: Institutional quality, FDI, ARDL, financial development, globalisation.

JEL code: E02, F00, F43.

Paper Type: Research article.

\footnotetext{
${ }^{1}$ Department of Economics, Goa Institute of Management, Goa, India, e-mail: chinmayaeco@gmail.com

${ }^{2}$ Humanities and Social Sciences, National Institute of Technology, Rourkela, India, e-mail: bikashranjan.mishra@gmail.com

${ }^{3}$ Department of Economics, Goa Institute of Management, Goa, India,

e-mail: btpriyadarshini@gmail.com

${ }^{4}$ Department of Economics, Sushilavati Government Women's College, Rourkela, India, e-mail: satpathy.lopa@gmail.com
} 


\section{Introduction}

Interestingly, there is a plethora of literature examining the relationship between institutional quality and economic growth which provide mixed evidence (Chong et al., 2000; Klein, 2005; Butkiewicz et al., 2006; Valeriani et al., 2011). Chong et al. (2000) establish the influence of institutional quality on economic growth when the country is poor. Further, they also find reverse causality from economic growth to institutional quality. Klein (2005) demonstrates both theoretically and empirically the relationship between institutional quality and economic growth. Butkiewicz et al. (2006) opine that good institutional promotes growth and development. Valeriani et al. (2011) find a positive impact of institutional quality on economic growth. After pioneer work on institutional quality by North (1990) and seminal work by Klein (2005), most of the studies empirically conclude that institutional quality affect economic growth positively (Thalassinos and Kiriazidis, 2003; Suryanto et al., 2017).

Several studies also examine the relationship between foreign direct investment (FDI) inflow and economic growth (Chang, 2010; Anwar et al., 2010; Inekwe, 2013; Mah, 2010; Azman-Saini et al., 2010; Kelly, 2016; Brahim et al., 2014). Chang (2010) finds FDI inflow influences economic growth directly through stimulating domestic investment in the short-run. Anwar et al. (2010) opine that the existence of the bi-direction linkage between FDI inflow and economic growth using simultaneous equation models. Inekwe (2013) finds bi-directional causality between FDI inflow and economic growth in Nigeria. On the contrary, Mah (2010) finds no unidirectional causality from FDI inflow to economic growth using small sample cointegration techniques in the case of China.

However, his study finds unidirectional causality from economic growth to FDI inflow. Further, Azman-Saini et al. (2010) find no direct impact of FDI inflow on economic growth using the generalized method of moments system estimator. However, they further find that economic freedom is the means which attracts FDI and hence, economic growth. Kelly (2016) finds that FDI inflow has an impact on GDP but it goes through the development of the financial sector. Similarly, Brahim et al. (2014) conclude that FDI inflow has an effect on economic growth but conditional to the development of institutions.

While a voluminous empirical study examines the relationship between institutional quality and economic growth, and FDI inflow and economic growth, however, the literature related to the nexus between FDI inflow and institutional quality is scanty. To the best of our knowledge, there are few studies that directly examine the relationship between FDI inflow and institutional quality (Jude and Levieuge, 2015; Buchana et al., 2012; Masron et al., 2013; Shah et al., 2016; Jindřichovská et al., 2020; Arifin, 2017; Suryanto and Thalassinos, 2017). Jude and Levieuge (2015) theoretically demonstrate that institutional quality affects FDI inflow through knowledge spillover. Buchan et al. (2012) find that FDI inflows increase to the 
countries with better institutional quality whereas its inflow decreases with poorquality institutions. They find that good institutional quality matters to FDI inflow. Further, they provide evidence that institutional quality has a positive and significant effect on FDI inflow. Masron et al. (2013) study the effect of institutional quality on FDI inflow in ASEAN-8. They find that institutional quality is an additional factor which attracts the FDI apart from cheaper labor cost. Shah et al. (2016) investigate the relationship between institutional quality and sectoral FDI inflow. They find no long-run and short-run causality from institutional quality to FDI inflow in the primary sector, and primary and service sectors, respectively. On the contrary, Jindřichovská et al. (2020) empirically examine the impact of FDI inflow and outflow to institutional environment in the Czech Republic. Their study finds the positive impact of FDI on institutional issues.

The present study differs from the existing literature in the following ways. First, this paper examines the impact of institutional quality on FDI inflow by considering selected emerging economies from South Asia. Although, institutional quality matters for FDI inflow but there exists heterogeneity in the institutional quality and FDI inflow in emerging countries from South Asia. Examining such relationship among emerging countries are not explored in the existing literature. The inclusion of institutional quality as input for FDI inflow augments economic growth at the aggregate level. Further, the use of institutional quality as input provides policy direction about the level of governance required at the institution in the country.

Second, though few studies focus on the relationship between institutional quality and FDI inflow at single country and multi-country analysis, none of the studies emphasizes the impact of institutional quality and FDI inflow in both the short-run and long-run along with strong causality. Therefore, this study focuses on the duration of causality along with strong causality which helps policymakers for necessary policy prescription to improve institutional quality.

Third, we investigate the impact of intuitional quality and FDI inflow by other key variables such as financial development and globalisation to avoid specification bias. Further, we consider the gross domestic product as a control variable to find a better relationship between FDI inflow and institutional quality. There are enough studies they provide evidence that globalisation, financial development, and gross domestic product are the key determinants of FDI inflow (Bitzenis, 2004; Alfaro et al., 2009; Pao et al., 2011).

\section{Overview of Institutional Quality and Foreign Direct Investment in Selected Emerging Countries from South Asian}

Table 1 gives an insight into the institutional quality and foreign direct investment inflow from selected emerging economies i.e., India, Bangladesh, Sri Lank, and Pakistan from South Asia. Six parameters constitute institutional quality i.e., voice and accountability, political stability and absence of violence/terrorism, government 
effectiveness, regulatory quality, rule of law, and control of corruption (Kaufmann et al., 2010). From Table 1, we find that Bangladesh comes first in the list of sample countries leaving India, Pakistan and Sri Lanka in their respective orders of institutional quality.

However, Sri Lanka performs better than other countries in terms of control of corruption, political stability, regulatory quality and rule of law. The largest democracy in the world, India could find its place next to Sri Lanka only. However, in terms of the effectiveness of government, and voice and accountability, India outperforms Sri Lanka. Surprisingly, Bangladesh who secured the first position in the overall institutional quality index was found to be the most deprived country in almost all sub-indices of institutional quality except for political stability and voice and accountability indices where she outstripped Pakistan.

FDI inflow data of emerging economics from South Asia is also reported in Table 1. The data shows the dominant FDI figures of India (\$23155.02 million) in comparison to the rest three emerging countries. To put it differently, the sum of the rest three countries does not even count half of the Indian FDI inflow figures. Sri Lanka (\$546.56 million) finds its lowest rank among these four countries. Pakistan and Bangladesh are marginally performing better, though, Bangladesh outperforms Pakistan of late. Year-on-year basis, data show that after the 2008 financial crisis, almost all four countries get affected but the severity is mainly borne by India.

Table 1. A Comparative Figure of Select Emerging Economies from South Asia with respect to Institutional Quality and Financial Direct Investment inflow

(The figures are the average values across time)

\begin{tabular}{|c|c|c|c|c|}
\hline$\downarrow$ Index $\backslash$ Countries $\rightarrow$ & Sri Lanka & India & Pakistan & Bangladesh \\
\hline Foreign Direct Index & $\frac{546.56}{\left(171.79^{\#}\right)}$ & $\begin{array}{l}23155.02 \\
\left(44458.5^{\$}\right)\end{array}$ & 2030.65 & 1153.74 \\
\hline 2. Institutional Quality Index & $\underline{0.01}\left(-2.04^{\#)}\right.$ & 0.06 & $\underline{0.01}$ & $\begin{array}{l}\mathbf{0 . 0 8} \\
\left(1.93^{\$}\right)\end{array}$ \\
\hline A. Control of Corruption & $\begin{array}{l}\mathbf{- 0 . 2 8} \\
\left(-0.15^{\$}\right)\end{array}$ & -0.42 & -0.94 & $\frac{-1.11}{\left(-1.5^{\#}\right)}$ \\
\hline Government Effectiveness & -0.14 & $\begin{array}{l}\mathbf{- 0 . 0 6} \\
\left(0.12^{\$}\right)\end{array}$ & -0.62 & $\frac{-0.76}{\left(-0.68^{\#}\right)}$ \\
\hline $\begin{array}{l}\text { C. Political Stability and } \\
\text { Absence of Violence/Terrorism }\end{array}$ & $\begin{array}{l}-\mathbf{- 0 . 8 9} \\
\left(0.09^{\$}\right)\end{array}$ & -1.18 & $\frac{-2.29}{\left(-2.81^{\#}\right)}$ & -1.38 \\
\hline Regulatory Quality & $\begin{array}{l}-\mathbf{- 0 . 1 5} \\
\left(0.19^{\$}\right)\end{array}$ & -0.37 & -0.66 & $\frac{-0.93}{\left(-1.13^{\#}\right)}$ \\
\hline Rule of Law & $\begin{array}{l}\mathbf{0 . 0 3} \\
\left(0.33^{\$}\right)\end{array}$ & 0.02 & -0.84 & $\frac{-0.85}{\left(-1.05^{\#}\right)}$ \\
\hline Voice and Accountability & -0.37 & $\begin{array}{l}\mathbf{0 . 4 3} \\
\left(0.46^{\$}\right)\end{array}$ & $\frac{-0.89}{\left(-1.17^{\#}\right)}$ & -0.46 \\
\hline
\end{tabular}

Note: (1) Bold Number represents highest among countries. (2) Underline represents lowest among countries. (3) \$ represents Highest and \# represents Lowest across the time period.

Source: Own calculations. 


\section{Data}

This study uses annual data from 2002 to 2016 for a panel of four emerging countries from South Asia. We select these four countries purely based on the upper- and lower-middle income groups defined by the World Bank, and the availability of data for each of the variables under consideration. We consider two major variables i.e., foreign direct investment inflow and institutional quality along with other key economic factors such as globalization, financial development and Gross Domestic Product to minimize specification bias. Further, GDP is taken as a control variable to find a better relationship between institutional quality and FDI inflow. Institutional quality is divided into six broad groups i.e., control of corruption (CC), government effectiveness (GE), political stability (PS), rule of law $(\mathrm{RL})$, regulatory quality (RQ), and voice and accountability (VA). It is quite difficult to use all these groups in a single regression model due to the high correlation among the variables. These individual institutional quality indicators, however, fail to provide a completemeasurement of overall institutions.

Therefore, to overcome this limitation, we followed the following procedure. We use principal component analysis (PCA) to construct institutional quality index (INSQF) using all the six institutional variables as computed by Globerman and Shapiro (2002), and Buchanan et al. (2012). Further, FDI inflow, Institutional Quality and GDP data are extracted from the World Bank database for four emerging economies i.e., Sri Lanka, India, Pakistan and Bangladesh from South Asia.

Other economic factors, the KOF Globalisation index is calculated on a yearly basis. It basically consists of economic, social and political globalization sub-indices. Furthermore, economic globalization index consists of trade globalization and financial globalization indices. Interpersonal globalization, informational and cultural globalization constitute social globalization sub-index. Political globalization sub-index constitutes of embassies, international organizations and treaties. Principal components analysis is used to select the sub-groups and the weights are determined to maximize the variation in the variables to create globalization index. ${ }^{5}$ Financial development index is taken from International Monetary Fund (IMF) data base. It is the constituents of eight subindices related to market and institution which is developed by the IMF (Svirydzenka, 2016).

\section{Methodology}

\subsection{Panel Unit Root Test}

First, we apply the Im-Pesaran-Shin (IPS) (Im et al., 2003) to check the stationarity of each variable under consideration in the study. The IPS panel unit root regression

${ }^{5}$ https://kof.ethz.ch/en/forecasts-and-indicators/indicators/kof-globalisation-index.html 
of the conventional ADF test with $\mathrm{N}$ sample groups observed over $\mathrm{T}$ time periods can be written as follows;

$\Delta y_{i, t}=\alpha_{i}+\pi_{i} t+\beta_{i} y_{i, t-1}+\sum_{j=1}^{k} \gamma_{i j} \Delta y_{i, t-1}+\varepsilon_{i, t}$

Where, ${ }^{\prime} y^{\prime}$ refers the time series, $\Delta$ is the first difference operator, $\boldsymbol{\varepsilon}_{\boldsymbol{i}, \boldsymbol{t}}$ is white noise disturbance term with variance, $\boldsymbol{\sigma}^{2}, \mathrm{i}=1,2, \ldots, \mathrm{N}$ show countries and $\mathrm{t}=1,2, \ldots, \mathrm{T}$ refers time. The $\Delta \boldsymbol{y}_{\boldsymbol{i}, \boldsymbol{t}-\mathbf{1}}$ terms on the right-hand side in equation (1) allow serial correlation with the objective of achieving disturbance term. Further, to test cross sectional dependency and heterogeneity across the group of countries, the study uses cross-sectional dependence (CD) and cross-sectional augmented IPS(CIPS) tests developed by Pesaran (2007).

\subsection{Panel Autoregressive Distributed Lag (ARDL) Test}

Second, we use panel ARDL-PMG (Pooled Mean Group) test introduced by Pesaran et al. (1999) to examine the relationship between institutional quality and FDI inflow along with other variables such as globalisation and financial development. The advantages of the approach are that it can test possible long-run relationships irrespective of the integration order of the variables i.e., I(1) or I(0). Moreover, this method gives consistent and efficient estimators as it removes the problems of endogeneity by including lag length for both endogenous and exogenous variables. The panel ARDL $(\mathrm{p}, \mathrm{q})$ model equation is as follows:

$$
\begin{aligned}
& \Delta F D I_{i t}=\alpha_{1 i}+\beta_{1 i} F D I_{i t-1}+\beta_{2 i} G I_{i t-1}+\beta_{3 i} I Q_{i t-1}+\beta_{4 i} F D_{i t-1}+ \\
& \sum_{j=1}^{p} \gamma_{1 i} \Delta F D I_{i t-j}+\sum_{i=0}^{q} \gamma_{2 i} \Delta G I_{i t-j}+\sum_{i=0}^{q} \gamma_{3 i} \Delta I Q_{i t-j}+\sum_{i=0}^{q} \gamma_{4 i} \Delta F D_{i t-j}+ \\
& \varepsilon_{1 i t}
\end{aligned}
$$

Where, FDI, GI, IQ and FD refers foreign direct investment, globalization index, institutional quality and financial development respectively. Further, $\Delta$ is the first difference operator. The criterial for lag length will be on the basis of AIC (Akaike Information Criterion) and SBC (Schwarz Bayesian Criterion). The null hypothesis of no cointegration in equation 1 gives $\left(\boldsymbol{H}_{\mathbf{0}}: \boldsymbol{\beta}_{\mathbf{1 i}}=\boldsymbol{\beta}_{\mathbf{2 i}}=\boldsymbol{\beta}_{\mathbf{3 i}}=\boldsymbol{\beta}_{\mathbf{4 i}}=\mathbf{0}\right)$ and the alternative hypothesis $\left(\boldsymbol{H}_{\mathbf{1}}: \boldsymbol{\beta}_{\mathbf{1 i}} \neq \boldsymbol{\beta}_{\mathbf{2}} \neq \boldsymbol{\beta}_{\mathbf{3 i}} \neq \boldsymbol{\beta}_{\mathbf{4} i} \neq \mathbf{0}\right)$. The ARDL bound testing procedure is based on the F-statistics or Wald statistics. Two bounds of critical values are considered for a given significance level (Pesaran et al., 2001). The first assumes that all variables are $\mathrm{I}(0)$, whereas the second assumes $\mathrm{I}(1)$. The null hypothesis is rejected if computed F-statistic value exceeds the upper critical bounds value. The cointegration test becomes inconclusive if F-statistic falls within the bounds. The null hypothesis cannot be rejected if F-statistics is lower than the lower bound value. 
Further, the study employs error correction model (ECM) to examine the short run dynamins of the variables. The ECM equation is reported as follows:

$$
\begin{aligned}
& \Delta F D I_{i t}=\alpha_{1 i}+\sum_{j=1}^{p-1} \beta_{1 i j} F D I_{i t-j}+\sum_{i=0}^{q-1} \beta_{2 i j} \Delta G I_{i t-j}+\sum_{i=0}^{q-1} \beta_{3 i j} I Q_{i t-j}+ \\
& \sum_{i=1}^{q-1} \beta_{4 i j} \Delta F D_{i t-j}+\mu_{1 i} E C T_{1, i t-1}+\varepsilon_{1 i t}
\end{aligned}
$$

The estimators and parameters of ARDL are obtained using the pooled mean group (PMG) method. PMG approach assumes heterogeneity of the short-term coefficients, whereas, for long-run coefficient, it is assumed to be identical and homogeneous for all individuals in the panel. Moreover, the ECM approach is considered to be consistent as it accounts for the individual characteristics and provides better results in the long-term relationship. Further, to check robustness, we apply another panel co-integration test developed by Pedroni (2004) to test long-run relationship between FDI inflow and institutional quality. This technique allows to consider the heterogeneity among individual country of the panel. Further, the test is also contained heterogeneity in long-run cointegrating vectors as well as dynamics in the short-run.

\subsection{Granger Causality}

The study uses Granger causality (Engle-Granger, 1987) test to find the causal links among the variables. Causality link is divided into three different categories i.e. long-run, short-run and strong causality.

Firstly, the co-efficient error correction term in equation 3 determines the long-run causality. For instance, long-run causality can be found by testing the null hypothesis, $\boldsymbol{H}_{\boldsymbol{o}}, \boldsymbol{\mu}_{\mathbf{1}}=\mathbf{0}$, against the alternative hypothesis, $\boldsymbol{H}_{\mathbf{1}}: \boldsymbol{\mu}_{\mathbf{1}} \neq \mathbf{0}$.

Secondly, the coefficient of the variables in first difference is used to find short-run causality. For example, in equation 3, we want to study short-run causality between institutional quality and FDI inflow with the null hypothesis $\boldsymbol{H}_{\mathbf{0}}: \boldsymbol{\beta}_{\mathbf{3 i}}=\mathbf{0}$, and the alternative hypothesis, $\boldsymbol{H}_{\mathbf{1}}: \boldsymbol{\beta}_{3 i} \neq \mathbf{0}$. Further, to study paired short-run causality such as causality from both globalization and institutional quality to FDI inflow with null hypothesis, $\boldsymbol{H}_{\mathbf{0}}: \boldsymbol{\beta}_{2 i}=\boldsymbol{\beta}_{3 i}=\mathbf{0}$, and alternative hypothesis, $\boldsymbol{H}_{\mathbf{1}}: \boldsymbol{\beta}_{2 i} \neq \boldsymbol{\beta}_{3 i} \neq \mathbf{0}$.

Finally, the coefficients of variables in first difference and coefficient of ECT are used to find strong causality. For instance, in equation 3, if we study the strong causality from institutional quality on FDI inflow, it can be obtained by testing the null hypothesis, $\boldsymbol{H}_{\mathbf{0}}: \boldsymbol{\beta}_{\mathbf{3 i}}=\boldsymbol{\mu}_{\mathbf{1}}=\mathbf{0}$, against the alternative hypothesis $\boldsymbol{H}_{1}: \boldsymbol{\beta}_{3 i} \neq \boldsymbol{\mu}_{1} \neq \mathbf{0}$. Similarly, if we want to test strong causality from globalization and institutional quality on FDI inflow then we can obtain by testing null hypothesis, $\boldsymbol{H}_{0}: \boldsymbol{\beta}_{2 i}=\boldsymbol{\beta}_{3 i}=\boldsymbol{\mu}_{\mathbf{1}}=\mathbf{0}$, against the alternative hypothesis $H_{1}: \beta_{2 i} \neq \beta_{3 i} \neq \mu_{1} \neq 0$. 


\section{Results and Discussion}

In this section, we talk about empirical results. Table 2 reports the descriptive statistics such as mean, median, standard deviation, maximum and minimum values of the variables under consideration. The mean value of FDI inflow and institutional quality are positive during the study period. Further, FDI inflow is more volatile than institutional quality. The meaning value globalisation, financial development, and gross domestic project are positive during the study period. Moreover, globalisation is more volatile than any other variable under consideration.

Table 2. Descriptive Statistics

\begin{tabular}{|l|l|l|l|l|l|}
\hline Variables & Mean & Std. Dev. & Max. & Min. & Obs. \\
\hline FDI & 21.42615 & 1.611586 & 24.51782 & 17.7726 & 60 \\
\hline $\begin{array}{l}\text { Institutional } \\
\text { Quality }\end{array}$ & .0380409 & .9884556 & 1.97214 & -2.03506 & 60 \\
\hline $\begin{array}{l}\text { Globalisation } \\
\text { Index }\end{array}$ & 54.53421 & 5.594732 & 61.8464 & 39.9992 & 60 \\
\hline $\begin{array}{l}\text { Financial } \\
\text { Development }\end{array}$ & .2849581 & .1007594 & .469782 & .126214 & 60 \\
\hline GDP & 26.01428 & 1.289548 & 28.54026 & 24.2809 & 60 \\
\hline
\end{tabular}

Source: Own calculations.

After discussing descriptive statistics, in the next step, we check the stationarity property of the variables using IPS (Im et al., 2003) panel unit root test. Table 3 presents the panel unit root test results of different variables in level as well as in the first difference. The results indicate that FDI inflow is stationary in the level i.e., $\mathrm{I}(0)$ whereas institutional quality (IQ) is non-stationary. Other economic factors such as globalization index (GI), financial development (FD), and gross domestic product (GDP) are non-stationary in the level. From the IPS panel unit root results in the first difference, we find institutional quality stationary. Moreover, other economic factors such as globalization, financial development and GDP are stationary in the first difference i.e., I(1). The mix results are found with $\mathrm{I}(0)$ and $\mathrm{I}(1)$ of variables which are pre-requisites for using ARDL model.

The disadvantages of the IPS Panel unit root test are that it assumes cross sectional independence and allows heterogeneity across panels. To overcome those disadvantages, we further use cross-sectional dependency unit root test developed by Pesaran (2004) and CIPS test developed by Pesaran (2007). The test is based on the average pairwise correlation of the ordinary least squares residuals for a panel by applying cross-sectional augmented IPS(CIPS). The cross-section dependency results are reported in Table 4 . The results indicate that the null hypothesis on no cross-sectional dependency can be rejected. It implies the existence of a serial correlation between cross-country error terms due to heterogeneous impact (Bhattacharaya and Naranya, 2015). Since there exists a cross-sectional dependency, traditional panel unit root test results will no longer valid under the assumption of 
cross-sectional independence (Rath et al., 2019). To avoid that problem, we use cross-sectional augmented IPS (CIPS) tests developed by Pesaran (2007). ${ }^{6}$ The results show that all the variables under consideration have the unit root.

Table 3. IPS Panel Unit Root Tests: Series in Level and in Difference

\begin{tabular}{|c|c|c|c|c|c|c|c|c|c|c|}
\hline Variables & \multicolumn{2}{|l|}{$\overline{F D I}$} & \multicolumn{2}{|l|}{$\overline{\overline{G I}}$} & \multicolumn{2}{|l|}{$\overline{I Q}$} & \multicolumn{2}{|l|}{$F D$} & \multicolumn{2}{|l|}{ GDP } \\
\hline (Level) & Intercept & Trend & Intercept & Trend & Intercept & Trend & Intercept & Trend & Intercept & Trend \\
\hline IPS & $\begin{array}{l}-2.05 \\
(0.01)\end{array}$ & $\begin{array}{l}-1.96 \\
(0.02)\end{array}$ & $\begin{array}{l}-3.40 \\
(0.00) \\
\end{array}$ & $\begin{array}{l}2.05 \\
(0.97)\end{array}$ & $\begin{array}{c}-0.63 \\
(0.26) \\
\end{array}$ & $\begin{array}{l}-0.49 \\
(0.30) \\
\end{array}$ & $\begin{array}{l}-0.11 \\
(0.45) \\
\end{array}$ & $\begin{array}{l}-0.59 \\
(0.27)\end{array}$ & $\begin{array}{l}2.37 \\
(0.99) \\
\end{array}$ & $\begin{array}{l}-2.45 \\
(0.00) \\
\end{array}$ \\
\hline (Difference) & \multicolumn{2}{|l|}{$D(L F D I)$} & \multicolumn{2}{|l|}{$D(G I)$} & \multicolumn{2}{|l|}{$D(I Q)$} & \multicolumn{2}{|l|}{$D(F D)$} & \multicolumn{2}{|l|}{$D(G D P)$} \\
\hline & Intercept & Trend & Intercept & Trend & Intercept & Trend & Intercept & Trend & Intercept & Trend \\
\hline IPS & $\begin{array}{l}-3.42 \\
(0.00)\end{array}$ & $\begin{array}{l}-3.07 \\
(0.00)\end{array}$ & $\begin{array}{l}-3.42 \\
(0.00)\end{array}$ & $\begin{array}{l}-2.23 \\
(0.012)\end{array}$ & $\begin{array}{l}-4.44 \\
(0.00)\end{array}$ & $\begin{array}{l}-5.04 \\
(0.00) \\
\end{array}$ & $\begin{array}{l}-4.44 \\
(0.00)\end{array}$ & $\begin{array}{l}-3.48 \\
(0.00)\end{array}$ & $\begin{array}{l}-3.87 \\
(0.00) \\
\end{array}$ & $\begin{array}{l}-1.21 \\
(0.11)\end{array}$ \\
\hline
\end{tabular}

Note: Here FDI: Foreign Direct Investment (natural logarithm transformed); GI:

Globalization Index; IQ: Institutional Index; FD: Financial Development Index; GDP:

Gross Domestic Product. The values in the parenthesis are corresponding $p$ value. $D($.

represents the first difference operator.

Source: Own calculations.

Table 4. Evidence of Cross-Sectional Dependence

\begin{tabular}{|l|l|l|}
\hline Variables & Pesaran(2004) Statistics & Avg. Abs. Corr. \\
\hline FDI & $5.80(0.00)$ & 0.611 \\
\hline Institutional Quality & $2.44(0.059)$ & 0.400 \\
\hline Financial Development & $-1.64(0.10)$ & \\
\hline Globalisation & $6.03(0.00)$ & 0.442 \\
\hline GDP & $9.41(0.00)$ & 0.635 \\
\hline
\end{tabular}

Note: Probability values in the parenthesis.

Source: Own calculations.

Next, we examine whether there is co-integration between FDI inflow and institutional quality. We apply panel ARDL-PMG developed by Pesaran et al. (1999). The long-term and short-term elasticity results of FDI inflow with respect to institutional quality are reported in Table 5. The lag-length is selected based on Akaike information criterion (AIC). The overall panel ARDL $(1,1)$ results say the existence of a long-run relationship between institutional quality and FDI inflow as coefficients of the variables are positive and statistically significant with a one percent level of significance. Further, other economic factors i.e., globalization and financial development also depicts the same long-run relationship with FDI inflow while controlling the variable, GDP. Moreover, the coefficients of globalization and financial development positively impacting the FDI inflow in the long-run. The findings of the long-run relationship between institutional quality and FDI inflow coincides with the finding of Syed et al. (2015). Further, the negative coefficient value of ECT indicates the process of convergences towards the long-run. For

\footnotetext{
${ }^{6}$ The results are not reported due to space constraint but available from the authors upon request.
} 
example, if there is any short-run disequilibrium, then the degree of adjustment will be -0.94 yearly to get long-run equilibrium. However, the coefficients of all the variables are statistically insignificant in the short-run. Robustness checking is done using another panel co-integration test developed by Pedroni (2004). The results show that there is an existence of a long-run relationship between FDI inflow and institutional quality. ${ }^{7}$ Further, other variables such as globalisation, financial development, and GDP have a long-run relationship with FDI inflow implies robustness of the Panel ARDL-PMG results.

Table 5. Panel ARDL-PMG results

\begin{tabular}{|c|c|c|c|c|}
\hline Dependent Variable: & \multicolumn{4}{|l|}{ LFDI } \\
\hline Variable & Coefficient & Std. Error & t-Statistic & Prob.* \\
\hline \multicolumn{5}{|l|}{ OVERALL PANEL } \\
\hline & \multicolumn{2}{|c|}{ Long Run Equation } & & \\
\hline GI & 0.16 & 0.03 & 5.49 & 0.00 \\
\hline IQ & 0.13 & 0.05 & 2.69 & 0.01 \\
\hline \multirow[t]{2}{*}{ FD } & 8.11 & 1.57 & 5.16 & 0.00 \\
\hline & \multicolumn{2}{|c|}{ Short Run Equation } & & \\
\hline ECT(-1) & -0.94 & 0.12 & -7.70 & 0.00 \\
\hline $\mathrm{D}(\mathrm{GI})$ & -0.04 & 0.09 & -0.50 & 0.62 \\
\hline $\mathrm{D}(\mathrm{IQ})$ & -0.01 & 0.06 & -0.24 & 0.81 \\
\hline $\mathrm{D}(\mathrm{FD})$ & -3.07 & 1.82 & -1.69 & 0.10 \\
\hline GDP & 1.35 & 0.77 & 1.75 & 0.09 \\
\hline $\mathrm{C}$ & -26.14 & 19.72 & -1.33 & 0.19 \\
\hline
\end{tabular}

Note: (1) Here LFDI: Foreign Direct Investment (natural logarithm transformed); GI: Globalization Index; IQ: Institutional Index; FD: Financial Development Index; GDP: Gross Domestic Product (2) D(.) represents the first difference operator (3) ECT(-1) represents the Error Correction Term.

Source: Own calculations.

Next, we report ECM results in Table 6 for individual countries. We find discrepancies in the results for individual countries in the short-run. If there is shortrun disequilibrium then the degree of adjustment varies from country to country. For example, the degree of adjustment for Bangladesh and India is -0.64 and -1.20 respectively. Further, the degree of adjustment for Pakistan and Sri Lanka is -0.88 and -1.03 respectively. The speed of adjustment of India and Sri Lanka is higher compared to Bangladesh and Pakistan to get long-run equilibrium.

The coefficient of institutional quality is negative and significant for India, Pakistan and Sri Lanka indicating the improvement of the institutional quality. However, Bangladesh shows poor institutional quality as institutional coefficient is positive and statistically significant. Among all the four countries, India has better

\footnotetext{
${ }^{7}$ The Pedroni(2004) cointegration test results are not reported due to space constraint but available from the authors upon request.
} 
institutional quality as the magnitude of the coefficient is small. The countries that have good institutional quality has a significant impact on FDI inflow. From the ECM results, other economic factor such as globalization has a positive impact on FDI inflow in the case of India and Pakistan whereas negative impact in the case of Bangladesh and Sri Lanka. Moreover, financial development is statistically significant in all four emerging countries from South Asia.

Table 6. ECM Results for Individuation Countries

\begin{tabular}{|c|c|c|c|c|}
\hline \multirow{2}{*}{$\begin{array}{l}\text { Dependent Variable } \\
\text { Variable }\end{array}$} & \multicolumn{4}{|c|}{ Foreign Direct Investment } \\
\hline & Coefficient & Std. Error & $\mathrm{t}$-Statistic & Prob.* \\
\hline \multicolumn{5}{|l|}{ Bangladesh } \\
\hline$E C T(-1)$ & -0.63 & 0.01 & -44.82 & 0.00 \\
\hline$D(G I)$ & -0.27 & 0.01 & -39.16 & 0.00 \\
\hline$D(I Q)$ & 0.15 & 0.01 & 19.96 & 0.00 \\
\hline$D(F D)$ & -3.55 & 25.39 & -0.14 & 0.90 \\
\hline$G D P$ & -0.63 & 0.21 & -2.95 & 0.06 \\
\hline$C$ & 23.89 & 116.03 & 0.21 & 0.85 \\
\hline \multicolumn{5}{|l|}{ India } \\
\hline$E C T(-1)$ & -1.20 & 0.06 & -19.68 & 0.00 \\
\hline$D(G I)$ & 0.13 & 0.02 & 5.38 & 0.01 \\
\hline$D(I Q)$ & -0.05 & 0.00 & -10.93 & 0.00 \\
\hline$D(F D)$ & 2.02 & 7.19 & 0.28 & 0.80 \\
\hline$G D P$ & 1.94 & 0.41 & 4.75 & 0.02 \\
\hline$C$ & -41.56 & 242.60 & -0.17 & 0.87 \\
\hline \multicolumn{5}{|l|}{ Pakistan } \\
\hline$E C T(-1)$ & -0.88 & 0.03 & -28.79 & 0.00 \\
\hline$D(G I)$ & 0.04 & 0.01 & 3.29 & 0.05 \\
\hline$D(I Q)$ & -0.11 & 0.01 & -9.18 & 0.00 \\
\hline$D(F D)$ & -6.58 & 5.01 & -1.31 & 0.28 \\
\hline$G D P$ & 3.04 & 0.45 & 6.79 & 0.01 \\
\hline$C$ & -69.23 & 262.31 & -0.26 & 0.81 \\
\hline \multicolumn{5}{|l|}{ Sri Lanka } \\
\hline$E C T(-1)$ & -1.03 & 0.05 & -22.65 & 0.00 \\
\hline$D(G I)$ & -0.07 & 0.00 & -21.74 & 0.00 \\
\hline$D(I Q)$ & -0.04 & 0.00 & -7.98 & 0.00 \\
\hline$D(F D)$ & -4.16 & 19.58 & -0.21 & 0.85 \\
\hline$G D P$ & 1.07 & 0.09 & 12.20 & 0.00 \\
\hline$C$ & -17.68 & 41.48 & -0.43 & 0.70 \\
\hline
\end{tabular}

Note: (1) Here LFDI: Foreign Direct Investment (natural logarithm transformed); GI:

Globalization Index; IQ: Institutional Index; FD: Financial Development Index; GDP:

Gross Domestic Product (2) D(.) represents the first difference operator. (3) ECT(-1)

represents the Error Correction Term.

Source: Own calculations. 
Next, our study applies the Wald statistics to find causality links between variables in three different ways i.e., long-run, short-run, and strong causality. The causality results are reported in Table 6 . From the long-run causality result, we find the existence of long-run causality from institutional quality to FDI inflow. However, the study fails to finds any short-run causality from institutional quality to FDI inflow. This result supports the findings of Shah et al.' (2016) study. Other economic factors such as globalization and financial development show long-run causality to FDI inflow in South Asian countries.

Globalization, institutional quality, and financial development coefficient are statistically insignificant when they are paired together to test strong causality. Further, individually, institutional quality does not strongly cause FDI inflow. However, when it is paired with either globalization or financial development then they together show strong causality to FDI inflow. Other economic factors such as financial development and globalization individually show strong causality on FDI inflow. Further, when they are paired with other variables then they depict strong causality except for the pair institutional quality and financial development.

Table 7. Causality Tests: Types and Direction

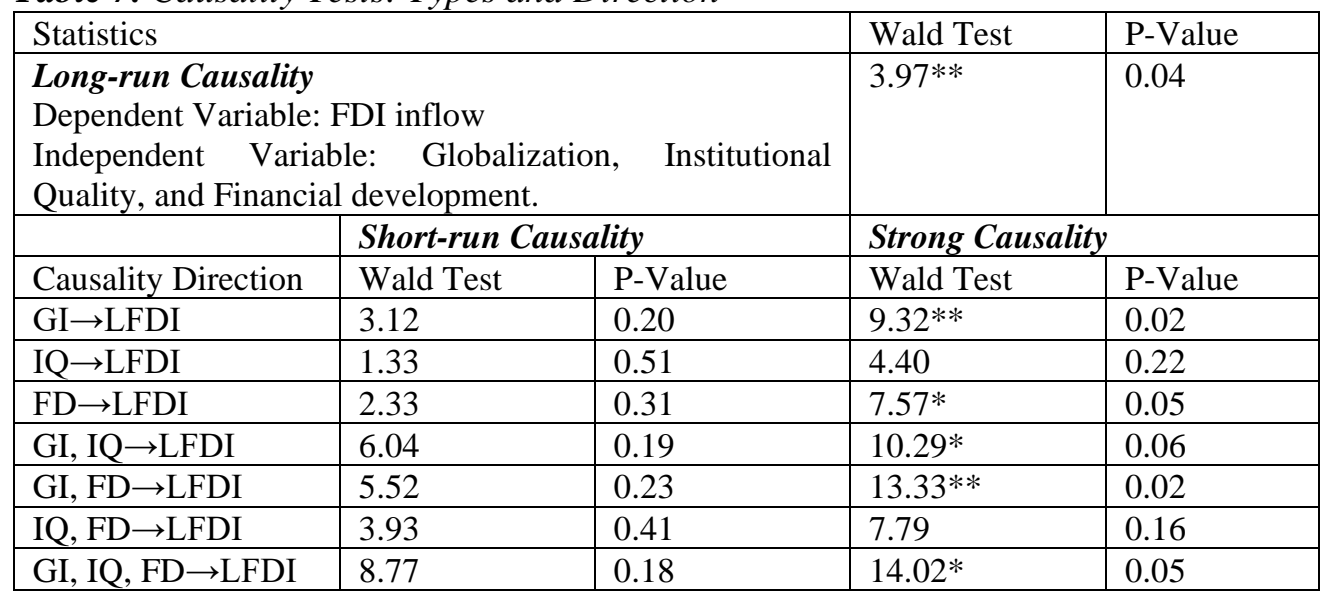

Note: $* *$ and $*$ indicate rejection of null hypothesis at 5 and 10 percent level respectively.

Source: Own calculations.

\section{Conclusion and Policy Implication}

The empirical studies support the relationship between FDI inflow and economic growth. However, the linkages between institutional quality and FDI inflow in emerging countries is limited. Using a panel data set of 2002-2016 for a sample of four selected emerging countries from South Asia, this study makes an empirical contribution with new policy implication to institutional quality and FDI inflow linkage. Buchana et al. (2012) in their seminal work indicate the importance of institutional quality and transmission channel to impact FDI inflow. Our study tries to explore not only linkage between institutional quality and FDI inflow but also a 
comparison of the said variables among individual countries.

Methodologically, our study followed six steps to examine the relationship between institutional quality and FDI inflow. First, the IPS panel unit root test is used to check stationarity property. Further, we use cross dependency (CD) and cross-sectional augments IPS tests to check cross-sectional dependency and heterogeneity across the group countries. Next, we use panel ARDL-PMG test (Pesaran et al., 1999) to check the existence of long-relationship among variables. Then, we apply the panel Granger causality test to check the direction of causality. Finally, for the robustness of results, we use the Pedroni co-integration technique.

The empirical result depicts the existence of a long-run relationship between institutional quality and FDI inflow. Other economic factors such as globalization and financial development have a long-run relationship with FDI inflow. The negative coefficient value of the error coefficient indicates the speed of adjustment to get long-run equilibrium. Moreover, the study finds the long-run causality from globalization, financial development and institutional quality to FDI inflow in selected emerging countries form South Asia.

However, the short-run unidirectional causality from institutional quality to FDI inflow is not found from the results. The study finds the strong unidirectional causality from financial development to FDI inflow. Similarly, globalization and institutional quality together strongly cause FDI inflow.

The findings give interesting policy insight for the policymakers in emerging countries. For example, to increase the FDI inflow, policy makers should focus on institutional quality along with globalization and financial development. All the variables should move together to have a positive impact on the FDI inflow in the emerging countries.

\section{References:}

Alfaro, L., Kalemli-Ozcan, S., Sayek, S. 2009. FDI, productivity and financial development. World Economy, 32(1), 111-135.

Anwar, S., Nguyen, L.P. 2010. Foreign direct investment and economic growth in Vietnam. Asia Pacific business review, 16(1-2), 183-202.

Attiaoui, I., Toumi, H., Ammouri, B., Gargouri, I. 2017. Causality links among renewable energy consumption, $\mathrm{CO} 2$ emissions, and economic growth in Africa: Evidence from a panel ARDL-PMG approach. Environmental science and pollution research, 24(14), 13036-13048.

Arifin, A.Z. 2017. The influence of financial knowledge, control and income on individual financial behavior. European Research Studies Journal, 20(3), 635-648.

Azman-Saini, W.N.W., Baharumshah, A.Z., Law, S.H. 2010. Foreign direct investment, economic freedom and economic growth: International evidence. Economic Modelling, 27(5), 1079-1089.

Aziz, O.G. 2018. Institutional quality and FDI inflows in Arab economies. Finance 
Research Letters, 25, 111-123.

Bhattacharya, M., Narayan, P. 2015. Output and labor productivity in organized manufacturing: A panel cointegration analysis for India. International Journal of Production Economics, 170, 171-177.

Bitzenis, A. 2004. Is globalization consistent with the accumulation of FDI inflows in the Balkan countries? European Business Review.

Brahim, M., Rachdi, H. 2014. Foreign direct investment, institutions and economic growth: Evidence from the MENA region. Journal of Reviews on Global Economics, 3, 328-339.

Buchanan, B.G., Le, Q.V., Rishi, M. 2012. Foreign direct investment and institutional quality: Some empirical evidence. International Review of financial analysis, 21, 81-89.

Chang, S.C. 2010. Estimating relationships among FDI inflow, domestic capital, and economic growth using the threshold error correction approach. Emerging Markets Finance and Trade, 46(1), 6-15.

Chong, A., Calderon, C. 2000. Causality and feedback between institutional measures and economic growth. Economics \& Politics, 12(1), 69-81.

Daude, C., Stein, E. 2007. The quality of institutions and foreign direct investment. Economics \& Politics, 19(3), 317-344.

Im, K.S., Pesaran, M.H., Shin, Y. 2003. Testing for unit roots in heterogeneous panels. Journal of econometrics, 115(1), 53-74.

IMF. 2003. World Economic Outlook: Growth and Institutions. http://www.imf.org/ external/pubs/ft/weo/2003/01/.

Inekwe, J.N. 2013. FDI, employment and economic growth in Nigeria. African Development Review, 25(4), 421-433.

Globerman, S., Shapiro, D. 2002. Global foreign direct investment flows: The role of governance infrastructure. World development, 30(11), 1899-1919.

Jindřichovská, I., Ugurlu, E., Thalassinos, E.I. 2020. Exploring the Trend of Czech FDIs and their Effect to Institutional Environment. International Journal of Economics and Business Administration, 8(1), 94-108.

Jude, C., Levieuge, G. 2015. Growth effect of FDI in developing economies: the role of institutional quality. Working papers 559, Banque de France.

Kaufmann, D., Kraay, A., Mastruzzi, M. 2009. Governance matters VIII: Aggregate and individual governance indicators 1996-2008. The World Bank.

Kelly, R. 2016. Does financial sector development enhance the relationship between FDI and economic growth? A comparative study of East African countries. Journal of Reviews on Global Economics, 5, 145-153.

Klein, M.W. 2005. Capital account liberalization, institutional quality and economic growth: theory and evidence, No. 11112. National Bureau of Economic Research.

Mah, J.S. 2010. Foreign direct investment inflows and economic growth of China. Journal of Policy Modeling, 32(1), 155-158.

Masron, T.A., Nor, E. 2013. FDI in ASEAN-8: Does institutional quality matter? Applied economics letters, 20(2), 186-189.

Pao, H.T., Tsai, C.M. 2011. Multivariate Granger causality between CO2 emissions, energy consumption, FDI and GDP: Evidence from a panel of BRIC (Brazil, Russian Federation, India, and China) countries. Energy, 36(1), 685-693.

Pesaran, M.H. 2006. Estimation and inference in large heterogeneous panels with a multifactor error structure. Econometrica, 74(4), 967-1012. 
Pesaran, M.H., Yamagata, T. 2008. Testing slope homogeneity in large panels. Journal of econometrics, 142(1), 50-93.

Rath, B.N., Akram, V., Bal, D.P., Mahalik, M.K. 2019. Do fossil fuel and renewable energy consumption affect total factor productivity growth? Evidence from cross-country data with policy insights. Energy policy, 127, 186-199.

Rodrik, D., Subramanian, A., Trebbi, F. 2004. Institutions rule: the primacy of institutions over geography and integration in economic development. Journal of economic growth, 9(2), 131-165.

Shah, S.H., Ahmad, M.H., Ahmed, Q.M. 2016. The nexus between sectoral FDI and institutional quality: Empirical evidence from Pakistan. Applied Economics, 48(17), 1591-1601.

Suryanto, T., Thalassinos, I.E. 2017. Cultural Ethics and Consequences in Whistle-Blowing among Professional Accountants: An Empirical Analysis. Journal of Applied Economic Sciences, 6(52), 1725-1731.

Suryanto, T., Thalassinos, E.Y., Thalassinos, I.E. 2017. Board Characteristics, Audit Committee and Audit Quality: The Case of Indonesia. International Journal of Economics and Business Administration 5 (3), 47-57.

Svirydzenka, K. 2016. Introducing a new broad-based index of financial development. International Monetary Fund.

Thalassinos, I.E. and Kiriazidis, T. 2003. Degrees of Integration in International Portfolio Diversification: Effective Systemic Risk. European Research Studies Journal, 6(12), 119-130, DOI: 10.35808/ersj/92.

Valeriani, E., Peluso, S. 2011. The impact of institutional quality on economic growth and development: An empirical study. Journal of Knowledge Management, Economics and Information Technology, I(6), 1-25. 